\title{
The Rebounding of the People's Action Party of Singapore in 2015: An Electoral Analysis of Three Hotly Contested Constituencies
}

\author{
MUSTAFA IZZUDDIN*
}

The 2015 Singapore General Elections (GE) produced a puzzling outcome. Although it was predicted by analysts that the People's Action Party (PAP) would rebound, the depth of victory by way of popular vote of 69.9 percent was confoundding. Given also that the Workers' Party of Singapore (WP) was expected to retain Aljunied Group Representation Constituency (GRC) as well as the Single Member Constituency (SMC) of Hougang and Punggol East, it further flummoxed analysts when the WP lost Punggol East to the PAP, and WP had its margin of victory reduced in both Aljunied and Hougang. Epitomising PAP's rebound was also the increased margin of victory in the PotongPasir SMC. Although the opposition, namely, the WP was expected to further pluralise the parliamentary system in Singapore by winning more seats in GE2015, the reverse took place in that the PAP not only rebounded from the 60.1 percent it received in GE2011, but also further entrenched its one-party dominance in governing Singapore. Based on an electoral analysis of three constituencies, Punggol East, PotongPasir and Aljunied, this article argues that these constituencies illustrate how the PAP rebounded while the WP retrogressed in GE2015. Pursuant to the electoral outcome, this article makes the case that there needs to be a re-evaluation when applying the concept of authoritarianism to Singapore's context.

Keywords: Singapore General Elections, Political Parties, Personality Politics, Neo-Authoritarianism

* Research Fellow, ISEAS-YusofIshak Institute, Singapore;

E-mail: mustafa@iseas.edu.sg

DOI: 10.16934/isr.17.2.201612.177 


\section{INTRODUCTION}

Surpassing all expectations, the People's Action Party (PAP) rebounded from 60.1 percent of the popular vote in the 2011 Singapore General Elections (GE) to 69.9 percent of the popular vote in the 2015 GE. The PAP achieved a substantial swing of 9.72 percent in its favour, with a high voter turnout of 93.56 percent of eligible voters. Not only had PAP retained all its seats as the incumbent, but it also wrested the Punggol East Single Member Constituency (SMC) from the incumbent Workers' Party of Singapore (WP). Moreover, the Aljunied Group Representation Constituency (GRC), the only GRC under political opposition, was only narrowly retained by the incumbent WP against a brand new makeshift PAP team in the 2015 GE. In fact, the winning margin in Aljunied GRC was so narrow that it forced a vote recount. In addition, Hougang SMC, a WP stronghold since 1991, was retained by the WP with a reduced margin of 57.7 percent in the $2015 \mathrm{GE}$ as compared to 64.8 percent in the 2011 GE. PotongPasir SMC, which was under political opposition for 27 years before it was lost narrowly to the PAP in the 2011 GE, was retained by the PAP with a much larger margin of victory in the $2015 \mathrm{GE}$.

While many psephologists predicted a bouncing back of the PAP in the 2015 $\mathrm{GE}$, few, if any, forecasted the depth of victory by way of popular vote in the 2015 GE. The general consensus among local political pundits was an increase in the 60.1 percent in the $2011 \mathrm{GE}$ to around 65-66 percent in the $2015 \mathrm{GE}$, and a status quo in the parliamentary seats between the PAP and the WP (Koh 2015a). That is, WP was expected to retain Aljunied GRC, Hougang SMC and Punggol East SMC, with the rest of the GRCs and SMCs going the way of the PAP, even when it came up against other opposition parties, namely the Singapore Democratic Party (SDP) and the Singapore People's Party (SPP). That the PAP secured close to 70 percent of the overall popular vote and wrested Punggol East SMC from the WP confounded political commentators, culminating in them probing deeper to make sense of this electoral outcome (Tan 2015a). That the WP also fared poorly in the 2015 GE, with WP's share of the vote in the constituencies it contested slipped 6.8 points from the $2011 \mathrm{GE}$ to 39.8 percent in the $2015 \mathrm{GE}$, also came as a great surprise. This is because WP was expected not just to emulate its success in GE2011, but also to make further inroads into parliament by winning even more electoral seats. WP's hope was for Singapore to shift from a one-party dominant to at least a one-and-a-half party system.

However, the reverse took place where PAP not only rebounded but also entrenched its dominance while WP began to run out of steam in its attempt to pluralise the parliamentary system in Singapore. Given this conundrum in the electoral politics of Singapore, this article seeks to answer the following twin questions: why did the PAP rebound so fantastically, surpassing all expectations; and why did the WP retrogress so dramatically, drifting further away from the goal 
of a one-and-a-half party system? In addition to this, what were some of the trends and implications from the battle between PAP and WP in the 2015 Singapore General Elections? To address these questions, this article presents an electoral analysis of three constituencies-one GRC and two SMCs-that were accorded significant coverage by the local media during the 2015 GE. By discussing the candidate profiles and campaign strategies (revolving around key electoral issues) of individuals in Punggol East and PotongPasir SMCs as well as the team of individuals in Aljunied GRC, this article posits the argument that these three constituencies illustrate how the PAP rebounded on the one hand while the WP retrogressed on the other, regarding Punggol East and Aljunied in GE2015. It is hoped that the analysis here will unravel some trends and implications that could be of modest significance in understanding the electoral politics of Singapore.

\section{PUNGGOL EAST SINGLE MEMBER CONSTITUENCY}

Punggol East was one of the newer SMCs as it was carved out in GE2011, although Punggol SMC had existed from 1959 to 1991 before it was absorbed into a GRC. It was Singapore's largest SMC and a fairly new town with 96 percent living in public housing and 4 percent in private homes. At the $2015 \mathrm{GE}$, there were 34,466 registered voters in the Punggol East constituency, of which 33,137 turned up to vote. Just as Punggol was governed by a PAP Member of Parliament (MP) from the very beginning, Punggol East also came under the charge of a PAP MP at the 2011 GE before the enforced resignation of that PAP MP over an extramarital affair in 2013 precipitated a by-election. It was won by WP's Lee Li Lian in a four-cornered race, making her the incumbent in the 2015 GE. She came up against Charles Chong in a straight fight between the WP and the PAP. In a closely-fought contest, Chong dislodged the incumbent Lee with a winning margin of 1,156 votes. Chong captured 51.8 percent to Lee's 48.2 percent of the vote, thus cutting short Lee's stewardship of the relatively new Punggol East SMC.

\section{Explaining Charles Chong's Dislodgement of the Incumbent}

Chong's victory could first and foremost be attributed to his candidate profile as a veteran politician with considerable experience in running a town council. The thinking behind the PAP's transfer of Chong from JooChiat SMC (absorbed into Marine Parade GRC) to Punggol East SMC was to leverage three important factors. First, Chong was a familiar face in Punggol East as some areas of this ward were under his stewardship when he was an MP in PasirRis-Punggol GRC from 2001 to 2011. Chong described his return to the constituency as a 'homecoming' where 'it feels like Chinese New Year when you visit old relatives' (Straits Times 2 August 2015). Second, Chong had a good track record in running a 
municipality when he was chairman of PasirRis and later, PasirRis-Punggol Town Council from 1997 to 2006. According to Chong, the financial position of the PasirRis-Punggol Town Council was in surplus and Punggol East SMC was in good financial health before the Punggol East ward was handed over to the WP when Lee won the by-election in 2013 (Channel NewsAsia 9 September 2015). Echoing the same was Deputy Prime Minister (PM) Teo Chee Hean who said: 'I was very sorry to hand them over. But we handed it over in good order, with surpluses to WP. Now they're part of a town council that is in deficit, I feel quite bad about that, too' (Channel NewsAsia 22 August 2015). Third, Chong was an experienced politician who had fought six general elections since he entered politics in 1988, but more importantly, he was a specialist in winning electoral dogfights as was evidenced when he contested as part of the winning PAP team in Eunos GRC in 1991 and later, JooChiat SMC in 2011 where he won by a mere 388 votes against the WP candidate who resided in that constituency. Chong was regarded as PAP's secret weapon in winning back lost seats because he was seen as a candidate whose forte was winning tough battles which included not cracking under pressure in hotspot wards.

The second reason for Chong's victory was to accentuate the simple message of reassurance to the voters that he was a problem-solving MP. He saw himself being deployed in Punggol East to rescue its residents from the clutches of the WP. That is, Chong could be counted upon to resolve the town council issues of governance and accounting lapses as it pertained to Punggol East, given that this ward came under the purview of the WP-run Aljunied-Hougang-Punggol East Town Council (AHPETC). Chong's proposed solution was to remove Punggol East from AHPETC to get the ward back to good financial health and restore the Ministry of National Development (MND) grants for the area. Only then would Chong be able to further improve the lives of the Punggol East residents through, for example, attending quickly to any municipal problem. Rather than adopting a swashbuckling approach to campaigning, Chong focused instead on a quieter method of walking the ground and conducting Meet-the-People Sessions. Even the political rallies were rather subdued with Chong reading from a prepared script. Importantly, as postulated by Chong, 'there's no secret formula. It's basically going out, meeting people and convincing them that you have a better programme' (Tan 2015b) That Chong was able to get the full backing of the PAP grassroots in Punggol East, despite him being the Chairman of the PAP Punggol East branch for less than three weeks, was critical for the campaign to commence quickly and effectively as one united force. In addition to providing the necessary logistical support for the electoral campaign, the PAP grassroots, by virtue of their deep familiarity of the Punggol East area, were also better able to convince the residents in the constituency to vote for PAP's Charles Chong.

Lastly, Chong's narrow win can be attributed to the fact that his dwelling on the Punggol East Town Council did not backfire, but instead paid off. In fact, 
Chong's entire campaign was premised on one uppermost issue: WP's mismanagement of the Punggol East Town Council within the wider rubric of AHPETC. Chong benefited from the constant harping by the PAP leadership at WP's lapses in running AHPETC, which, in the end, helped swing middle-ground votes towards the PAP. Given moreover that all seats were being contested in the $2015 \mathrm{GE}$, the PAP leadership cautioned the national electorate that there was no guarantee that the PAP would be in government after the polls. Noted PAP Chairman Khaw Boon Wan, "There is no "safe seat" where victory is assured ...We cannot be sure of a PAP government on Sept 12' (Khalik and Tham 2015). This candid caution led to many voters, chiefly those occupying the middle ground, casting their ballot for the PAP including for Chong in Punggol East SMC.

\section{Explaining Lee Li Lian's Mediocre Performance}

One plausible reason for Lee's loss was that she failed to live up to expectations after her sensational by-election victory in 2013 . This could be partly due to Lee only being able to serve as an MP for about two and the half years before the 2015 GE was called in Singapore; and also partly due to Lee being understandably absent from the Punggol East ward for several months upon giving birth to a baby girl in the middle of 2014. Taken together, Lee's lack of visibility in Punggol East meant that she was unable to leave a lasting imprint on the constituents as the incumbent. This is compounded by the fact that WP's grassroots branch in Punggol East was far weaker and less cohesive than their PAP counterparts. Moreover, when compared to Chong who was about 1.5 times her age, she was a neophyte when it came to being a parliamentarian, running a town council, and launching a potent electoral campaign. Lee's non-elitist background where she was better able to connect with ordinary Singaporeans in the 2013 byelection, when compared to PAP's candidate who belonged to the elite class, also lost its lustre in GE2015. That is, Lee's profile as an average Singaporean was no longer a winning formula in GE2015 because Chong was himself not an elite; he was the longest-serving PAP backbencher in parliament. It was essentially her youthful exuberance as well as the advantage of incumbency that allowed Lee to level the playing field and compete with Chong neck and neck at the 2015 GE. In the end, Lee's by-election victory in 2013 was more of a false dawn in WP's rise in the electoral politics of Singapore.

The second reason for Lee's mediocre performance in the $2015 \mathrm{GE}$ was to do with the constituents of Punggol East voting on Lee's track record on municipal issues rather than her contributions by way of speeches in the Singapore Parliament. It was more about Lee's performance as a town councillor than as a parliamentarian as far as the electorate in Punggol East were concerned. In fact, Lee conceded as much that her loss may be down to 'municipal issues' although she 
qualified her remark by saying that the AHPETC dispute 'hardly cropped up' when speaking to residents during her walkabouts (TODAY 12 September 2015). The loss attributed to municipal considerations baffled Lee as she felt her homeground knowledge was an advantage, and that 'she has met many residents as she could, tracked the homes she visited, and helped them with problems as workmanship issues with new Build-To-Order flats' (Sim 2015a). Given also that there were many middle-aged couples in Punggol East where both husband and wife tended to work, Lee promised to lobby for more childcare facilities during the 2013 by-election campaign. That there was still a lack of childcare facilities when GE2015 began could have given the impression to the voters of Punggol East that Lee was incapable of delivering on her campaign promise. Thus, despite Lee pledging to continue lobbying for more amenities in the Punggol East vicinity such as hawker centres and markets during her rallies (Lee 2015a), her pledges appeared not to resonate with 51.8 percent of the Punggol East voters. In contrast, while Chong acknowledged the lack of municipal facilities in Punggol East, he was hesitant to make any firm campaign promises as he was unsure of the financial health of the ward. All in all, most of the constituents of Punggol East were not convinced by Lee's track record to vote for her again in 2015.

Lastly, Lee's narrow loss could be attributed to the overall retrogression of the WP in the 2015 GE. The AHPETC dispute led to an erosion of support for the WP, with the implicit implication that the WP was unable to run a town council as effectively as the PAP. This erosion of support for WP nationwide also reduced Lee's capture of the vote in Punggol East, especially given that municipal issues in this ward were the responsibility of AHPETC. The fact that it was WP's strongman Low ThiaKhiang who was fire-fighting not just the PAP leadership but also Charles Chong as it pertained to the AHPETC controversy suggests that Lee Li Lian may not be completely familiar with town council issues, and as such, unable to retort robustly. This, in turn, could have worked against Lee when soliciting votes from the residents of Punggol East. Despite WP's conventional electoral strategy to use political rallies to excite the crowd which traditionally assembled in large numbers, and in so doing, cast their ballot for the WP, this failed to translate into votes for the party in GE2015. The utilisation of the social media by the WP to reach out to the voters, particularly those of the younger generation, remained effective in that it still gave the PAP a run for its money, although the PAP candidates themselves had made use of the social media to better engage with the Singaporean electorate. The gulf of support on the social media which favoured the WP over the PAP was clear-cut, although it could be argued that the social media divide between WP and PAP was fast narrowing. There was, in a sense, an equalisation of the effects because of the proliferation and active utilisation of the social media by both parties. In the case of Punggol East, Lee was far more techsavvy and active on the social media as opposed to Chong. This was evidenced by 
Chong having about 2000 followers on Facebook whilst Lee having around 8 times more followers on her Facebook public page. Therefore, one lesson from Chong's win and Lee's loss at Punggol East was that although the social media was an integral facet of the political landscape in Singapore, elections were not won on the Internet; but rather, they were won on the ground.

\section{POTONG PASIR SINGLE MEMBER CONSTITUENCY}

PotongPasir was the smallest electoral constituency in Singapore and one of the oldest towns in the country with predominantly public housing. PotongPasir was also the longest SMC to withstand the arbitrary redrawing of electoral boundaries in Singapore. In fact, the boundaries of PotongPasir have remained untouched since 1984, the year PotongPasir fell to the opposition after being controlled by the PAP since 1968, the year the PotongPasir ward was created. After being the MP of the ward for 27 years from 1984 to 2011, Chiam See Tong moved out of PotongPasir to helm the Bishan-Toa Payoh GRC in GE2011 while introducing his wife, Lina Loh (Chiam), as his successor for PotongPasir under the banner of the SPP. It was, in a sense, a bad judgement call because Loh narrowly lost to the PAP candidate, Sitoh Yi Pin, who then became the incumbent in GE2015. Loh, by virtue of being one of the best performing losers in GE2011, took up the position of a Non-Constituency Member of Parliament (NCMP) from 2011 to 2015. At GE 2015, there were 17,407 registered electors in the PotongPasir SMC, of which 16,158 turned up to vote. Compared to GE2011 where Sitohwon by the slimmest of margins of 114 votes or 50.4 percent of the vote, his margin of victory in GE2015 was much wider, in that he defeated Loh by more than 30 percentage points in the polls. Sitoh captured 66.4 percent to Loh's 33.6 percent of the vote, thus retaining the PotongPasir SMC for the PAP. Sitoh's win was the largest swing in a single-seat constituency for the PAP in GE2015. This straight fight between Sitoh and Loh only came to pass after an independent candidate by the name of Tan Lam Siong pulled himself out of the electoral race on Nomination Day. Sitoh's surging win also meant that for the first time in 31 years, the Chiams would not have a presence, whether as an MP or NCMP, in parliament.

\section{Explaining Sitoh Yi Pin's Surging Victory}

The primary reason for Sitoh's surging win in PotongPasir was his track record as the MP for the ward. In fact, Sitoh made his track record the centrepiece of his electoral campaign, not least because he was a near-anonymous figure in parliament as opposed to his work on the ground as a town councillor. In Sitoh's words, 'I went back to look at our manifesto for 2011. We promised many things and I'm happy to report we fulfilled them all-both hardware and "heartware" 
(Channel NewsAsia 17 August 2015). In GE2011, Sitoh had 23 items in his manifesto but surpassed his target by delivering 120 projects and programmes (Lee 2015b). These included expanding the facilities of the community club to comprise a well-stocked gym, bank facilities and supermarket, continuing lift upgrading, home-improvement initiatives, a free shuttle service, a food drive called Rose (Rice, Oil, Sugar and Essentials) to deliver groceries to needy house-holds, and Medi-Assist, a scheme to help defray costs of doctor visits and medication (Loh 2015). Arguably, Sitoh's track record would have resonated with the low-income, elderly, disabled as well as the middle class which may have wanted to see a balance between municipal reforms and sustaining the rustic charm of the town. Premising his campaign on a mix of self-reliance and communitarianism to maintain a healthy track record in PotongPasir, Sitoh postulated this: 'Having a kampung spirit does not mean that we have to live in a kampung with no amenities. Kampung spirit is about the community ("gotong royong") spirit. You must cheer for one another, care for one another and be happy with one another' (The New Paper 10 September 2015).

Secondly, Sitoh's win could be attributed to his candidate profile as a determined loyalist with intimate local knowledge of the PotongPasir ward. Even after two failed attempts in GE2001 and GE2006, Sitoh stuck with PotongPasir, and was finally rewarded for his determination and loyalty to the ward when he won in GE2011 and became a first-term MP. That Sitoh made use of his familiarity with the ward to deliver on his campaign promises after GE2011 also resonated with the constituents as they found him to be a doer. That Sitoh was on good terms with the Chiams also found favour with the voters of PotongPasir, as their admiration for Chiam See Tong as an iconic figure remained intact. Noted Sitoh: 'I've known Mr and MrsChiam for 15 years now and I have enormous respect for him. Mr Chiam's 27 years of legacy is intact. I have no intention to replicate it' (Channel NewsAsia 17 August 2015). Sitoh's non-elitist background as a chartered accountant of a firm he set up more than 20 years ago could have also worked in his favour, given how former PM Lee Kuan Yew's condescending dismissiveness of Chiam's average GCE 'O' Level results (as opposed to then-PAP candidate of PotongPasir, Mah Bow Tan's stellar academic credentials) spectacularly backfired (Da Cunha 1997, 75). That is, Mah was defeated by Chiam in the 1984 GE, which then led to Chiam becoming synonymous with PotongPasir.

Lastly, Sitoh's impressive performance was plausibly due to the practice of pork-barrel politics, which has long been associated with the PAP during election time. Central to pork-barrelling was the use of government funds for lift upgrading to entice voters in PotongPasir in order to win their support. As lamented by Lina Loh, 'The swing towards the PAP, the biggest carrot, was upgrading ... I have a feeling residents were afraid that if they voted for me, upgrading of the lifts might stop-some of them may believe that' (Lim 2015a). As outlined by Sitoh in his 
manifesto, 32 units in total across eight blocks in PotongPasir will benefit from the lift upgrading programme. Cited also in Sitoh's manifesto was him promising residents of PotongPasir 22 new goodies including additional bus services plying the PotongPasir area and more day care centres for the elderly (Yoong 2015). Such a manifesto was in keeping with the PAP, knowing that the electorate expected it, being explicit on what awaited those who voted for PAP MPs in terms of estate improvements. That Sitoh was able to fulfil his promises after GE2011 meant that he could also make good on his pledges after GE2015. This, in turn, would have inspired confidence in the voters, chiefly those receptive to change, that Sitoh was the right man for the job.

\section{Explaining the End of the Chiam Era}

The foremost reason for Lina Loh (Chiam)'s dismal performance was that she was not her husband, Chiam See Tong, whom the residents of PotongPasir SMC had the utmost respect for, and deep loyalty towards. The loyalty and affecttion for Chiam by the residents of PotongPasir were not replicated and extended to his wife, despite Chiam supporting her throughout the election campaign. In other words, the residents of PotongPasir were not simply going to transfer carte blanche their votes from Chiam to Loh just because the latter was Chiam's wife. In fact, it can be argued that Chiam's departure from PotongPasir SMC provided the voters with the perfect excuse to vote for Sitoh instead so as to revel in the goodies on offer by the PAP candidate. That the Chiam factor was embedded in Potong Pasir meant that the residents of the ward were unlikely to vote out Chiam and make him lose face. Chiam's national political role as an oppositional icon was also an important factor for the residents of PotongPasir to stick with him. As noted by current PM Lee Hsien Loong himself, who has held Chiam in high regard, Chiam 'stands up for Singapore and closes ranks, and that is really the norm that should prevail in the political scene in Singapore' (TODAY 27 November 2015). As such, because of Chiam, residents of PotongPasir were more willing to forego amenities enjoyed by other wards and not be held to ransom with the upgrading carrot. According to one resident, 'I believe 70 percent of voters here would still vote for MrChiam, should he decide to run again in PotongPasir' (Tan 2015c). In contrast, Loh's performance as an NCMP on the national stage had divided opinion, given how she was poor in both the content and delivery of her speeches, although her oratorical skills did improve with experience during her time in parliament. But tellingly, Loh was unable to relate to the voters the extent to which her husband could, given his charm, stature, and gentlemanly spirit in abundance.

Secondly, Lina Loh's twin campaign messages of championing political pluralism and safeguarding the Chiam legacy was not bought by 66.4 percent of 
the electorate in PotongPasir SMC. For the former, Loh made her record as an NCMP the cynosure of her electoral campaign, although in her manifesto, she pledged 'incremental improvements' such as an upgraded hawker centre and market in the ward (Channel NewsAsia 9 September 2015). As opined by Loh, 'I ran for PotongPasir because I wanted to be the voice for PotongPasir. I was the NCMP and I was proud to have spoken up fearlessly for them as well as for all Singaporeans' (Loh 2015). Loh expressly emphasised the fact that she had spoken up 83 times in Parliament as an NCMP, the second-highest among the currentlyserving house members; as well as attended 113 out of 115 sittings-absent twice when her sister passed on-and raised two adjournment motions, including on financial and accounting irregularities and lapses in government ministries and statutory boards (Channel NewsAsia 9 September 2015). However, her focus on national issues such as creating high-paying jobs for Singaporeans, a low-tax environment, sustainable health care and equitable growth failed to gain traction when compared to Sitoh's one-track focus on local municipal issues as far as residents of PotongPasir were concerned. So, despite Loh's highly commendable record as an NCMP, it was the wrong formula to win back PotongPasir. Loh misread ground sentiment in that residents voted for the one who can best improve their estate. The fact that Sitoh had to over-deliver on his promises and fulfil them was to the benefit of the voters.

For the latter, Loh piggybacked on her husband to persuade the residents of PotongPasir to keep alive Chiam's brand of politics by ensuring that the Chiam flag continues to fly high in the constituency. She also pressed home the point that SPP's long experience in managing the ward and the rejection of the PAP goodies by PotongPasir residents was central to Chiam's legacy in this constituency. However, leveraging on her husband's success had its downsides, chief of which was the perception created that Loh was over-dependent on her husband, and as such, possessed no identity of her own as a politician. When Loh suggested that PotongPasir residents would get two MPs if they voted for her (Loh as a full-time MP and her husband as an ex-MP), she found little resonance in the constituency. Given also that Chiam's legacy encompassed the effective running of the Potong Pasir Town Council, there were no political ramifications from the AHPETC saga on the SPP in PotongPasir SMC. However, the fact that 2015 was a fairly exceptional year for the PAP, in that it was Singapore's $50^{\text {th }}$ birthday and Lee Kuan Yew had passed on, also helped swing votes towards the PAP nationwide, including in PotongPasir. In the end, it can be said that PotongPasir residents were now enjoying the best of both worlds: Chiam's legacy in PotongPasir remained intact; and Sitoh's victory meant more goodies for the ward.

Lastly, Loh's loss in two subsequent elections, which appeared to indicate the end of the Chiam era, could also be attributed to the failure of the Chiam-centric SPP to have a credible succession plan for the future of PotongPasir in the post- 
Chiam period. Such a plan would be crucial, given that both the Chiams were now senior citizens, and it was only be a matter of time before the Chiam factor outlived its usefulness as far as the SPP regaining control of the PotongPasir SMC was concerned. As opined by a resident, 'I think people want an MP who can serve them in the long-term' (Koh 2015b). Enacting such a plan was also made even more urgent given the fact that the SPP was one of worst-performing parties nationally with the largest drop in vote share, acquiring 27.1 percent of votes in the seats it contested in 2015 as opposed to 41.4 percent in 2011. Despite the dismal showing, Loh has refused to rule out contesting again in PotongPasir; but having recognised the importance of succession planning, Loh has intimated that the SPP would vigorously identify and groom new and young political blood to take the party forward, with Loh seeing herself serving as a mentor for the political neophytes.

\section{ALJUNIED GROUP REPRESENTATION CONSTITUENCY}

Formed in 1988 when the GRC system was first introduced into Singapore's electoral system, Aljunied was a five-member GRC comprising the most number of voters in the country. Notably, the electoral boundaries of Aljunied have been redrawn several times, such as when the Eunos division was moved from Eunos GRC to Aljunied GRC in 1997, the Punggol South division from Cheng San GRC to Aljunied GRC in 2001, and the Kaki Bukit division from Marine Parade GRC to Aljunied GRC in 2011. Prior to becoming a GRC, Aljunied was an SMC, which was formed in 1959 up until it became defunct in 1988. Whether as an SMC or a GRC, Aljunied was helmed by the PAP until 2011 when WP won convincingly in the elections that year. In GE2015, however, WP won by a narrow margin of 2,612 votes in a ward that had 148,142 registered voters, of which 138,474 turned up to vote. WP's vote share dropped from 54.7 percent in GE2011 to 51.0 percent in GE2015. In other words, WP retained Aljunied by a whisker when it received 51.0 percent to the PAP's 49.0 percent in GE2015, resulting in a swing of 3.8 percent in favour of the PAP as opposed to GE2011 where there was a swing of 10.8 percent in favour of WP. Given also that the difference in the margin of victory in GE2015 was less than two percentage points, a recount was sought by the PAP team, the only recount eligible during the 2015 GE. WP's win in Aljunied GRC, along with retaining the Hougang SMC stronghold, meant that the opposition was returned to parliament with the same number of seats, that is, six seats, in GE2015 as it did in GE2011.

\section{Explaining the Narrow Win of the WP 'A' Team}

The most feasible reason for the WP retaining Aljunied, albeit narrowly, was 
the fielding of the same 'A' team of 2011 for the 2015 GE. The highly-publicised move of Low ThiaKhiang from Hougang SMC to Aljunied GRC, which was crucial to WP's Aljunied win in the $2011 \mathrm{GE}$, was not replicated in 2015. That is to say, Low made no similar political pilgrimage in 2015 to capture another GRC, which was likely to have been East Coast GRC where WP's 'B' team was to be fielded. It was hoped that if WP was to put up its second-best team in a GRC where it received 45.2 percent of the vote in 2011, its chances of winning another GRC while holding on to Aljunied (contiguous with East Coast) could be bolstered. In the main, it was, on hindsight, the right decision for Low to stay put in Aljunied, because instead of acquiring an even greater swing in its favour nationwide in 2015 when compared to 2011, the WP suffered a dramatic vote swing against it in Aljunied, retaining the GRC by a whisker. That WP proceeded with the same team while the PAP fielded a completely different team in Aljunied also worked in WP's favour as the visibility factor was firmly on the side of the WP. That is, the Aljunied electorate was more likely to recognise the candidates from the WP as opposed to the PAP, which, in turn, would have impacted, to a certain extent, the party chosen by the Aljunied voters in 2015. Not surprisingly, the newly-formed PAP team-dubbed the party's 'suicide squad'-viewed themselves as 'underdogs' in 'fight[ing] very hard to regain the trust of the majority of the Aljunied residents' (Channel NewsAsia 8 September 2015). It is noteworthy that in electoral terms, it is extremely difficult, even near impossible, for any challenger to the incumbent to emerge victorious by achieving a 5-6 percent swing in their favour after just one election cycle. The visibility factor was crucial in Low and two of his comrades, Faisal Manap and Pritam Singh winning their respective wards, despite two other of Low's comrades-Sylvia Lim and Chen Show Maolosing their wards (Tan 2015d). This 3:2 win in the wards underpinned WP's narrow victory in Aljunied, riding chiefly on the incumbency advantage.

Secondly, WP's Aljunied win could be attributed to the capture of the Malay vote. Just as the bulk of the Malay vote was secured by Aljunied's WP team in GE2011, which, in turn, contributed to dislodging the PAP from a GRC for the first time, the same was the case in GE2015 when WP emerged victorious in the two wards of Aljunied with a sizeable Malay electorate higher than the national average of 14 percent. Singh won his Eunos ward, where Malay voters comprised 20 percent of the electorate, with about 55 percent of the vote while Faisal clinched over 1000 more votes than his rival in the Kaki Bukit ward where Malay voters comprised 24 percent of the electorate (Low 2015; Oorjitham 2015). That Faisal convincingly defeated the Malay candidate from the PAP, ShamsulKamar, suggests that the PAP made an error in its political judgement to rebuff Kahar Hassan by replacing him with Shamsul. This is because Kahar, PAP's initial choice to be fielded in the Kaki Bukit ward of Aljunied GRC, had become exceedingly popular in Kaki Bukit as signified by the cases overseen by Kahar at 
the Meet-the-People session increasing from 5-7 to 30-35 every week (Tan 2015e). That many residents were upset at Kahar's removal from Kaki Bukit with some even shedding tears suggests that Kahar had developed an emotional bond with the residents (Tan 2015e). So, had Kahar come up against Faisal, there was a possibility of Kahar winning the ward, which in turn, could have impacted the overall outcome of Aljunied GRC: either WP's victory could have been even narrower, or WP could have lost Aljunied altogether, especially if more Malay voters in other parts of Aljunied were to also strike a chord with Kahar. But while the Malay vote appeared to be cast in favour of the WP in Aljunied, the Malay vote nationwide was likely to have been cast in favour of the PAP for two key reasons. First, PAP's capture of close to 70 percent of the popular vote in GE2015 meant that the Malays, which are a significant minority voting bloc, could have voted for the PAP in large numbers. Second, the fact that both Prime Minister Lee Hsien Loong and Minister-in-charge of Muslim Affairs, Yaacob Ibrahim thanked the Malay community for giving the strong support and mandate to the PAP suggests that the large voter swing witnessed in GE2015 could have been partly due to the PAP winning the Malay vote (Yaacob 2015).

Lastly, WP retained Aljunied because the party's continued emphasis on political pluralism appeared to strike a chord with the slim majority of voters in Aljunied GRC. In the same way, WP retained Hougang SMC (adjacent to Aljunied GRC) with a reduced margin of victory when compared to GE2011. In accordance with WP's election manifesto titled 'Empower Your Future', WP called for empowering Singaporeans by constituting a 'system of government where there are adequate checks and balances without political gridlock' (TODAY 11 September 2015). In other words, Singaporeans, particularly in constituencies where WP was contesting, were exhorted to keep faith with the WP to remain the alternative voice in a PAP-dominated parliament. The WP rallies-the most attended of any political party-also reflected this standpoint in a boisterous fashion. Despite the reverse psychology employed by the PAP leadership on there being no guarantee of a PAP government after the polls, political pluralism still held sway in Aljunied. To enhance WP's chances to get into parliament, the local social media sites, chiefly those critical of the government such as The Online Citizen also played a pivotal role in influencing voting behaviour among Singaporeans in favour of political pluralism.

\section{Explaining the Creditable Performance of the PAP Underdog Team}

One conceivable reason for the surprisingly creditable performance by the PAP's only underdog team of GE2015 was the trading of barbs over the AHPETC dispute during the electoral campaign, which, in the end, appeared to favour the PAP as far as middle-ground support was concerned. Castigating the WP by the 
PAP elites and cadres over its financial lapses, with the deliberate implication of portraying WP to be incompetent in running a trouble-free town council, was a recurring characteristic during the electoral campaign. Unsurprisingly too that the WP adopted a defensive posture to counter the allegations by elucidating to the voters that the WP has already cleaned up their books, and that the whole AHPETC affair was a quintessential case of bullying by the PAP. Although the AHPETC affair seemed to have hijacked the entire electoral campaign in the constituencies contested by the WP, especially Aljunied, this electoral strategy did not surprisingly backfire on the PAP. Rather, it compelled the WP to backpedal and be preoccupied in dousing the AHPETC blaze (Law 2015). The message from the PAP leadership was a simple one: if the WP was unable to run a town council competently, how can it be entrusted with the responsibility to govern the country? Perhaps because the middle ground voters were disappointed with the performance of the WP to the extent of inferring that their support had been taken for granted since 2011, there was a noticeable vote swing in favour of the PAP in 2015.

Secondly, PAP's determination to go all out to win back Aljunied in 2015 could have found sufficient traction with the residents of Aljunied GRC. For example, the PAP rolled out detailed plans to further transform the Aljunied area with new MRT stations, better amenities and a spruced-up waterway, as highlighted by Prime Minister (PM) Lee Hsien Loong when speaking at a PAP rally in Aljunied during the electoral campaign (Lee 2015c). Seen against the context of the PAP government making policy adjustments and reengaging the electorate through the 'Our Singapore Conversation' initiative, it was hoped that Aljunied voters, like voters elsewhere, would give PAP credit for the marginal leftward shift in policy since GE2011 (Au Yong and Tham 2015). That party strongmen such as PM Lee, Deputy PM Tharman Shanmugaratnam and Emeritus Senior Minister Goh Chok Tong visited Aljunied to shore up support for their comrades contesting in Aljunied also showed that PAP was serious in winning back this GRC. A past MP of Aljunied GRC, ZainulAbidin Rasheed, was also actively involved in the grassroots, particularly in the Eunos ward which he had taken care of before being defeated in GE2011. This is despite the fact that the PAP fielded in Aljunied GRC the only team without an anchor Minister. The last Minister to helm Aljunied GRC was George Yeo, who congratulated the PAP underdog team for doing a 'very good job' to regain the support of the Aljunied electorate (Sim 2015b). The presence of PM Lee appeared to be particularly significant as he was perceived as one of PAP's more personable politicians alongside Deputy PMs Teo Chee Hean and Tharman. It was no wonder then that the PAP decided to capitalise on the popularity of PM Lee by putting up his poster in every constituency so much so that SPP's Lina Chiam queried on her Facebook 'Is the Prime Minister standing in PotongPasir SMC?' (Lim 2015b). Arguably, politics was not just local but also personal in Singapore. Personality politics, as epitomised by PM Lee, was also a 
crucial factor in the electoral outcome; and in Aljunied's case, PM Lee's appearance is likely to have helped swing the votes in favour of the PAP just as Low ThiaKhiang's magnetism was critical in WP retaining the GRC, albeit narrowly.

Lastly, PAP's underdog Aljunied team were beneficiaries of national occurrences and circumstances. Of note were the feel-good effect on voters as a result of Singapore's Golden Jubilee (SG50) in that Singapore, a small state steeped in vulnerability (see Leifer 2000), has been able to not only survive but also flourish over the course of 50 years against all odds; the Lee Kuan Yew effect on voters in that his demise evoked sentiments of sympathy and gratitude for the pioneer generation of leaders, chief of whom was Lee Kuan Yew himself; and the need for greater vigilance coupled with good political leadership to navigate Singapore through an anarchic external environment increasingly defined by transnational terrorism. That polling day was fixed on September 11, although perhaps coincidental, was also a sobering reminder of Singapore's vulnerability to external threats and the attendant need to safeguard the national security of the country. Taken together, along with the goodies handed out by the PAP government to the pioneer generation to court the silver vote (Koh 2015c), it is reasonable to suggest that the above factors impacted the voting behaviour of Aljunied in favour of the PAP.

\section{CONCLUSION}

The one common thread running through the three constituencies discussed in this article is that the PAP rebounded in GE2015 on the one hand while, on the other hand, the credibility of the opposition and in particular of the WP was on a knife-edge. The retrogression witnessed in the weak and fragmented opposition camp in GE2015 further reinforced the notion that opposition unity is a myth in Singapore. That is, the opposition cannot unite as a single entity to give PAP a run for its money, with flip-flopping, party-hopping, infighting, mudslinging and backstabbing commonplace in the opposition camp. Far from moving towards a one-and-a-half party system, PAP's stunning victory in GE2015 entrenched its one-party dominance in Singapore, as was explicated by renowned local academic, Chan Heng Chee as far back as the 1970s (Chan 1976). While other long-lasting political parties such as the Institutional Revolutionary Party in Mexico, the Liberal Democratic Party in Japan and the Indian National Congress in India have all been ousted from power after governing their respective countries for decades, the PAP has thus far defied the odds by continuing to govern the country since the 1959 General Elections.

That said, this one-party dominance need not be viewed in binary terms in that the political opposition has outlived its usefulness. Rather as Deputy PM Tharman intimates, 'It is important for the opposition to reflect on what happened 
- not just in terms of whether the electorate didn't know better or the electorate made a mistake-but how they could have done better in their strategies ... We need a more reflective attitude after each election, and on how the opposition can continue to play a constructive and positive role in Singapore politics, as they must' (Yang 2015). Despite the setback encountered by the opposition, not least the WP, it would be to the benefit of Singapore if the opposition, whether singly or collectively, engages in smart politics underpinned by realism and pragmatism. Calling for sweeping changes and the removal of the PAP government all at once by competing in all electoral seats, despite the opposition themselves being unproven, inexperienced, and arguably incapable of governing the country, seemed to have been unwise and counterproductive, as evidenced by the results of GE2015. As is also evident in the three constituencies examined here, the electorate is not averse to political pluralism, but it would also like to see an opposition that is constructive, competent and responsible, alongside the incumbent PAP still governing the country. In short, the electorate, in general, wants Singapore to have a PAP-led government with a credible political opposition in tow.

The analyses of the three constituencies in this article also elucidates that there was a litany of factors to account for why the PAP rebounded fantastically and the WP retrogressed so dramatically. Issues, events and themes that were local, national and even external in nature informed and shaped the voting behaviour of Singaporeans in GE2015. Political personalities, namely Lee Hsien Loong, Low ThiaKhiang and Chiam See Tong, also played a role in influencing the decision of voters, chiefly which party to cast their ballot for. This underscores the importance of individuals in electoral politics. The utilisation of the social media, which has revolutionised electoral politics worldwide (Bruns et al. 2016) will remain a mainstay of future general elections in Singapore. While it is difficult to say which factors mattered more than others, one thing's for sure: the electorate handed a strong mandate to the PAP. Presumably erring on the side of caution for fear of a freak election or to reward the PAP for its hard work to enact much-needed policy changes after its poor showing in GE2011, Singaporeans voted in a cautiously pragmatic fashion by plausibly putting the interests of the country first. In other words, GE2015 showed that the Singapore voter rewards a political party for its success, and not its failure.

One salient implication from the PAP being given a resounding vote of confidence by the electorate is the continuity of a strong government, which in turn, facilitates political stability and policy coherence. This is particularly significant in fostering an attractive business environment and boosting consumer confidence in Singapore. That several top captains of industry talked up the Singapore economy post-GE2015 at a time of regional and global political and economic turmoil testifies to the trust of, and relief for, a continuity in a PAP-led strong and stable government (The Business Times 21 September 2015). Given the con- 
ventional wisdom of the government's performance legitimacy resting on its delivery of economic promises and goods, a point succinctly made early on by a German-American political theorist, Carl Joachim Friedrich (1974, 114), the electoral outcome presented the PAP with the ideal start towards defending, if not bolstering, its track record. This stability-through-continuity denouement in Singapore was perceived as a breath of fresh air in a region where national politics are in a constant state of flux and instability, not least inside neighbouring Malaysia (see Saravanamuttu 2016). Concomitantly, a strong and stable government is crucial for a small state such as Singapore to safeguard its national security against internal and external threats (see Desker and Ang 2015).

However, it must be noted that 2015 was an exceptional year in that there would be no repeat of the effects of SG50 or the demise of Lee Kuan Yew. As such, from an electoral politics perspective, the 69.9 percent achieved by the PAP is likely to be more the exception than the rule. As to what the PAP would achieve in future elections would depend on its performance legitimacy, particularly in the post-Lee Hsien Loong period, and the credibility of the alternative, that is, the quality of the political opposition in Singapore. Despite the setback faced by the opposition in GE2015 against the backdrop of a one-party dominant state, the battle between the PAP and WP is likely to be resurrected after the introspection by the WP of its dismal performance in GE2015, with other political parties such as the SPP and SDP playing perhaps only a bit-part role in the electoral politics of Singapore, going forward.

Situating the analyses of the three constituencies in this article within the theoretical context of the term authoritarianism, which, in its different variants, have been employed (at times, overzealously) to describe the governing regime in Singapore (see Tan 2012; Ortmann 2011; Verwij and Pelizzo 2009; Means 1996), the GE2015 electoral outcome suggests that there needs to be a rethink when applying the concept of authoritarianism to Singapore's political (electoral) context. Given how one party dominance became further entrenched after GE2015, despite the fact that there was an opening for greater political pluralism in Singapore's parliamentary system, with every electoral seat being contested for the first time in Singapore's young political history, it can be said that even if Singapore continues to be described in authoritarian terms, authoritarianism has been so mainstreamed that it has come to be viewed as a positive label by the political elites as well as perhaps a term not relatable to the majority of the electorate in the way the voters cast their ballot in GE2015. This, in turn, renders the concept of authoritarianism, which has tended to be viewed in negative terms, somewhat meaningless in its applicability. Perhaps in this counter-narrative of neo-authoritarianism, Singapore is arguably both at once congruent and anomalous in this renewed paradigm shift regarding authoritarianism in Asia, where the old negative connotation of the term has outlived its usefulness. 


\section{REFERENCES}

Au Yong, Jeremy and Yuen-C. Tham. 2015. 8 reasons for surge of support. Straits Times (Singapore), September 13, http://www.straitstimes.com/politics/8-rea sons-for-surge-of-support

Bruns, Axel, Gunn Enli, Eli Skogerbo, Anders Olof Larsson, and Christian Christensen. eds. 2016. The Routledge Companion to Social Media and Politics. New York: Routledge.

Chan, Heng Chee. 1976. The Dynamics of One Party Dominance: The PAP at the Grassroots. Singapore: Singapore University Press.

Channel News Asia, 2015. PotongPasir: PAP Incumbent SitohYih Pin to Defend Hot Seat, August 17, http://www.channelnewsasia.com/news/singapore/poto ng-pasir-pap/2054910.html

Channel News Asia. 2015. Vote for a Party Whom You Trust to Manage your Money and Town Council: DPM Teo, August 22, http://www.channelnewsasia.com/ news/singapore/vote-for-a-party-whom-you/2050646.html

Channel News Asia, 2015. Hard Slog for PAP Team to Overcome Hostility in Aljunied, September 8, http://www.channelnewsasia.com/news/specialreports/ sgvotes2015/latest/hard-slog-for-pap-team-to/2107834.html

Channel News Asia, 2015. Workers' Party 'Deliberately Misquoted Me' on Punggol East Funds: Charles Chong, September 9 http://www.channelnewsasia. com/news/singapore/workers-party/2115390.html

Channel News Asia, 2015. PotongPasir Residents Will Get 'Two MPs' With Me: Lina Chiam, September 9, http://www.channelnewsasia.com/news/singapore/ potong-pasir-residents/2112880.html

Da Cunha, Derek. 1997. The Price of Victory: The 1997 Singapore General Election and Beyond. Singapore: Institute of Southeast Asian Studies: 75.

Desker, Barry and Cheng Guan Ang. eds. 2015. Perspectives on the Security of Singapore: The First 50 Years. Singapore: World Scientific.

Friedrich, CJ, 1974. Limited Government: A Comparison. New Jersey: PrenticeHall: 114.

Khalik, Salma and Tham, Yuen-C, 2015. No Guarantee PAP Will Be in Government After

Polls: Khaw Boon Wan. Straits Times (Singapore), September 8, http://www.straits times.com/politics/no-guarantee-pap-will-be-in-government-after-polls-khawboon-wan

Koh, Gillian, 2015a. GE2015 Hustings: Let's Focus on Policy, Not Political Grandstanding. IPSCommons, August 30, http://www.ipscommons.sg/ge2015-letsfocus-on-policy

Koh, Valerie, 2015b. Sitoh Retains PotongPasir with Much Larger Majority. Today (Singapore), September 12, http://www.todayonline.com/ge2015/sitoh-retai 
ns-potong-pasir-much-larger-majority

Koh, Tommy, 2015c. Ten Reflections on GE2015. Straits Times (Singapore), September 17, http://www.straitstimes.com/opinion/ten-reflections-on-ge-2015

Law, Elizabeth, 2015. Hot Spots: In Aljunied GRC: Is It All About Town Council Issue? The New Paper, September 3, http://www.tnp.sg/news/singapore-news/ hot-spots-aljunied-grc-it-all-about-town-council-issue

Lee, Li Lian, 2015a. Speech by Punggol East SMC Workers' Party Candidate. YouTube, September 5, https://www.youtube.com/watch?v=Ty4TLswepKo

Lee, Meixian, 2015b. Continuity is Key in PotongPasir: Sitoh. The Business Times (Singapore), September 10, http://www.businesstimes.com.sg/governmentecono my/continuity-is-key-in-potong-pasir-sitoh

Lee, Hsien Loong, 2015c. Speech by PAP Secretary-General at Aljunied GRC Rally. YouTube, September 4, https://www.youtube.com/watch?v=JOFGWIT $\underline{4 o p I}$

Leifer, Michael. 2000. Singapore's Foreign Policy: Coping with Vulnerability. London: Routledge.

Lim, Yan Ling, 2015a. Singapore People's Party 'Not Giving Up on PotongPasir.' Straits Times (Singapore), September 14, http://www.straitstimes.com/politics/ ge-2015-singapore-peoples-party-not-giving-up-on-potong-pasir

Lim, Yan Liang, 2015b. GE2015: Posters of PM Lee in PotongPasir Go Against Essence of Election, Says Lina Chiam. Straits Times (Singapore), September 2, http://www.straitstimes.com/politics/ge2015-posters-of-pm-lee-in-potongpasir-go-against-essence-of-election-says-lina-chiam

Loh, Ronald, 2015. Sitoh Yih Pin Retains PotongPasir SMC by Big Margin. The New Paper, September 12, http://www.tnp.sg/news/singapore-news/sitoh-yihpin-retains-potong-pasir-smc-big-margin

Low, Aaron, 2015. GE2015: Workers' Party Squeaks Through in Aljunied GRC. Straits Times (Singapore), September 12, http://www.straitstimes.com/politics/ ge2015-workers-party-squeaks-through-in-aljunied-grc

Means, Gordon Paul. 1996. Soft Authoritarianism in Malaysia and Singapore. Journal of Democracy 7(4): 103-17.

Oorjitham, Santha, 2015. All Eyes on How the Malays Vote. The Star (Malaysia), September 10, http://www.thestar.com.my/news/nation/2015/09/10/all-eyeson-how-the-malays-vote

Ortmann, Stephan. 2011. Singapore: Authoritarian but Newly Competitive. Journal of Democracy 22(4): 153-164.

Saravanamuttu, Johan. 2016. Power Sharing in a Divided Nation: Mediated Communalism and New Politics in Six Decades of Malaysia's Elections. Singapore: ISEAS and Malaysia: GIRD.

Sim, Royston, 2015a. GE2015: PAP's Charles Chong wins Punggol East SMC with 51.76 Percent of Votes. Straits Times (Singapore), September 11, http:// 
www.straitstimes.com/politics/ge2015-paps-charles-chong-wins-punggol-eastsmc-with-5176-per-cent-of-votes

Sim, Walter, 2015b. GE2015: George Yeo Says PAP Team in Aljunied GRC did 'Very Good Job' in Winning Back Voters. Straits Times (Singapore), September 18, http:/www.straitstimes.com/politics/ge2015-george-yeo-says-papteam-in-aljunied-grc-did-very-good-job-in-winning-back-voters

Straits Times (Singapore). 2015. Punggol East: 'Homecoming' for PAP Veteran Charles Chong. August 2, http://www.straitstimes.com/politics/punggol-easthomecoming-for-pap-veteran-charles-chong

Tan, Kenneth Paul. 2012. The Ideology of Pragmatism: Neo-liberal Globalisation and Political Authoritarianism in Singapore. Journal of Contemporary Asia 42(1): 67-92.

Tan, Eugene, 2015a. Why the PAP won big. Today (Singapore), September 12, http://www.todayonline.com/ge2015/why-pap-won-big

Tan, Tam Mei, 2015b. Veteran Politician Shares his Secret to Winning Tough Fights. The New Paper, September 17, http:/www.tnp.sg/news/singaporenews /veteran-politician-shares-his-secret-winning-tough-fights

Tan, Judith, 2015c. Hot Spot: Has Sitoh Stepped out of Chiam's Shadow in PotongPasir? The New Paper, September 5, http://www.tnp.sg/news/singaporenews/hot-spot-has-sitoh-stepped-out-chiams-shadow-potong-pasir

Tan, Martino, 2015d. 5 Things to Ponder over in Workers' Party's Close Shave at Aljunied GRC. Mothership.sg, September 13, http://mothership.sg/2015/09/ 5-things-to-ponder-over-in-workers-partys-close-shave-at-aljunied-grc

Tan, Martino, 2015e. Ex-potential Aljunied PAP Candidate Kahar Hassan Revealed He Wasn't Invited to PAP Manifesto Launch. Mothership.sg, August 31, http://mothership.sg/2015/08/ex-potential-aljunied-pap-candidate-kahar-hassanrevealed-he-wasnt-invited-to-pap-manifesto-launch

The Business Times (Singapore). 2015. Singapore after the GE, September 21, http://www.businesstimes.com.sg/views-from-the-top/singapore-general-elec tion/singapore-after-the-ge

The New Paper, 2015. Sitoh: I'm like Jackie Chan, September 10, http://www.tnp. sg/news/singapore-news/sitoh-im-jackie-chan

Today (Singapore). 2015. S'pore Ready for Critical, Balanced Parliament, September 11, http://www.todayonline.com/ge2015/spore-ready-critical-balancedparliament

Today (Singapore). 2015. GE2015: Candidates React to Polling Day Results, September 12, http://www.todayonline.com/ge2015/ge-2015-candidates-react-po lling-day-results

Today (Singapore). 2015. PM Lee Calls for Political Unity, Cites Chiam See Tong as an Example, November 27, http://www.todayonline.com/singapore/pmlee-calls-political-unity-cites-chiam-see-tong-example 
Verweij, Marco and Pelizzo, Riccardo. 2009. Singapore: Does Authoritarianism Pay? Journal of Democracy 20(2): 18-32.

Yaacob, Ibrahim, 2015. DrYaacob Thanks Malay-Muslim Community. YouTube, September 11, https://www.youtube.com/watch?v=X3PbkNOq2mY

Yang, Calvin, 2015. GE2015: Opposition Can Continue to Contribute to Singapore, Says DPM Tharman. Straits Times (Singapore), September 14, http://www. straitstimes.com/politics/ge-2015-opposition-can-continue-to-contribute-to-si ngapore-says-dpm-tharman

Yoong, Ren Yan, 2015. PotongPasir: Sitoh Keeps It Strictly Local. The Middle Ground, September 9, http://themiddleground.sg/2015/09/09/potong-pasir-si toh-keeps-strictly-local/ 